\title{
Carabid beetle assemblages associated with urban golf courses in the greater Helsinki area
}

\author{
JARMO SAARIKIVI, LAURA IDSTRÖM, STEPHEN VENN, JARI NIEMELÄ and D. JOHAN KOTZE
}

\author{
Urban Ecology Research Group, Department of Environmental Sciences, PO Box 65, FI-00014, University of Helsinki, Finland; \\ e-mails: jarmo.saarikivi@helsinki.fi, laura.idstrom@helsinki.fi, stephen.venn@helsinki.fi,jari.niemela@helsinki.fi, \\ johan.kotze@helsinki.fi
}

Key words. Carabidae, ground beetles, anthropogenic habitats, conservation, species assemblage, biodiversity, Helsinki area

\begin{abstract}
Golf is a popular sport, with increasingly large areas of urban and peri-urban land being designated for golf course development. Yet, more than half of the land area of a typical golf course is considered rough and out-of-play areas that can, if managed appropriately, provide habitats for wildlife. Using pitfall traps, 6944 carabid beetles belonging to 72 species were collected from five urban golf courses and three areas designated for golf course development around the city of Helsinki, Finland in 2007. The courses were rich in carabid species and distinct in their species assemblages. Golf courses were dominated by habitat generalists, species capable of flight and medium to large-sized species. The three courses with areas designated for further golf course development showed that the assemblages of beetles associated with these golf courses have retained many elements from the pre-existing habitats. The oldest golf course is characterised by a more evenly distributed and diverse carabid beetle assemblage, probably due to its higher habitat heterogeneity and longer successional development. However, even this golf course is dominated by generalist species, implying that golf courses may not provide suitable habitats for specialists. It is assumed that the high species richness of golf courses is attributed to the high habitat diversity of these environments, ranging from the strongly human-modified to more natural patches, which provide habitats for many generalist and open-habitat species. Golf courses may, however, with the appropriate management of out-of-play areas provide an opportunity for conserving biodiversity.
\end{abstract}

\section{INTRODUCTION}

Worldwide, 55 million people play golf on over 30000 golf courses (Farrally et al., 2003). Many countries are currently experiencing a golfing boom (Terman, 1997) that has lasted for several decades. New courses are being built at a rate that makes golf course development one of fastest growing types of land development in the world (Terman, 1997; Thien et al., 2004). Therefore, the effect of golf courses on the environment is a hotly debated topic in many countries (Dodson, 2000). In fact, golf is a sport that is in the environmental spotlight, because golf courses occupy large areas of land, often close to urban centres where human welfare, ecosystem health, water quality and other environmental issues are of paramount importance (Stangel \& Distler, 2002).

An average 18-hole golf course comprises 54 ha of land (Terman, 1997) and approximately $70 \%$ of that area is considered rough or out-of-play areas that could be used to create significant wildlife habitats (Tilly, 2000; Santiago \& Rodewald, 2004). Golf courses are typically heterogeneous, characterised by various types of soil, small water bodies, forest patches, sand bunkers and vegetation of variable height from highly managed greens and fairways to roughs and fields that are often left in an almost unmodified state (e.g. Santiago \& Rodewald, 2004). This habitat heterogeneity may influence biodiversity at the local scale of the golf course. Appropriate habitat management could over time lead to the enhancement of regional biodiversity (Tanner \& Gange, 2005). Small animals, such as insects benefit from the variety of habitat types found on a golf course, enhancing local biodiversity (e.g. Lopez \& Potter, 2003; Daniels \& Emmel, 2004; Porter et al., 2004; Tanner \& Gange, 2005).

The species assemblages of some urban habitats are poorly documented and the potential of urban green space for contributing to the maintenance of biodiversity is often not appreciated (Niemelä, 1999; Savard et al., 2000). To understand how biodiversity is affected by human actions, such as urbanization, it is important to study the responses of organisms to land-use change and to evaluate the relevant processes in urban habitats. This understanding could provide a framework for the sustainable management of urban habitats (Grandchamp et al., 2000). As such, extensive golf courses may be useful in preserving and protecting species, and even in elevating biodiversity, especially in and around urban centres.

In this study the carabid beetle (Coleoptera: Carabidae) community of golf courses in the Helsinki region, southern Finland, was investigated. Specifically, the aim was to characterise the diversity and assemblage structure of carabid beetle communities and determine whether there exist distinct beetle assemblages characteristic of these intensively managed and actively used green space areas. It is hypothesized that golf courses will be characterised by generalist and open-habitat carabid species, especially those with good dispersal ability. The kind of carabid assemblages associated with the habitat structure of golf courses and the management needed for maintaining diverse species assemblages on golf courses are determined. 


\section{MATERIAL AND METHODS}

\section{Study sites}

Of the about 120 golf courses in Finland, over 30 are within $50 \mathrm{~km}$ of the city of Helsinki $\left(60^{\circ} 10^{\prime} \mathrm{N}, 24^{\circ} 56^{\prime} \mathrm{E}\right)$ and five within the city limits, two of which are full-sized, 18-hole courses. Three of these five courses and two additional courses, one in each of the neighbouring cities of Espoo and Vantaa, were included in this study (Fig. 1). All of these courses are within $20 \mathrm{~km}$ of the centre of Helsinki and are used throughout the snow-free season. The number of players visiting the courses each day varies from a couple of players on less optimal days up to over a thousand per day. The average number of rounds played on a full-sized golf course in Finland is 20000 per season, though over 34000 rounds are played on some of the most popular courses (Laukkanen et al., 2006).

The most centrally located golf course included in this study is Tali (6 km from the city centre). This full-sized course was established in 1932 and is the oldest golf course in Finland. This course is located in the park of an old manor, which also contains facilities for other sports activities, such as football. The total area of the park is about 100 ha, of which the golf course is about 55 ha. The park is close to the sea and is surrounded by residential areas and an old refuse pit that was covered with soil in the 1980s.

Vuosaari golf course is another full-sized course in Helsinki. It was established in 2001 some $14 \mathrm{~km}$ northeast of the city centre. The total area for golf is about 50 ha, and the course is surrounded by residential areas and forest. The course is situated in open parkland by the sea.

Paloheinä golf course is an open access 9-hole course founded in 1996 and located about $10 \mathrm{~km}$ north from the city centre. It is 15 ha in size, surrounded by forest, agricultural land and residential areas. This course is the most frequently used golf course in Finland, often with over 1000 visitors per day (Anon., 2005) and it is planned to be extended in a couple of years.

Gumböle golf course (28 ha) is a 9-hole course established in 1991 in Espoo, a neighbouring city of Helsinki. The course is situated about $19 \mathrm{~km}$ northwest of the Helsinki city centre and is surrounded by forest and agricultural land. This course will also be extended to a full-sized course in the future.

The fifth course included in this study is the Hiekkaharju golf course in Vantaa, another neighbouring city of Helsinki. Hiekkaharju, is a 9-hole course established in 1999, 17 ha in size and located $17 \mathrm{~km}$ north of the Helsinki city centre. This course is surrounded by agricultural land and residential areas and is also scheduled to become a full-sized course. The areas at Paloheinä, Gumböle and Hiekkaharju that are to be incorporated into the extended courses were also included in this study.

\section{Carabid beetle sampling}

Carabid beetles were collected using pitfall traps (diameter of opening $65 \mathrm{~mm}$, volume $250 \mathrm{ml}$ ). The traps were sunk into the ground with the openings flush with the surface. A $70 \%$ aqueous propylene-glycol solution ( $30 \mathrm{ml}$ per trap) was used to kill and preserve the trapped insects. Brown plastic lids $100 \mathrm{~cm}^{2}$ in size were placed a few centimetres above the traps to prevent dilution by rainfall. The traps were placed in differently managed vegetation types at the golf courses and the areas of three courses to be extended, including fairways, fairway edges, roughs, forest patches and sand bunkers, that is, a representative spectrum of the vegetation types at these courses.

Five pitfall traps were placed at $5 \mathrm{~m}$ intervals along a transect through each vegetation type at each golf course. Some vegetation types were sampled more than once per golf course, while others were not sampled if they were not available at a par-

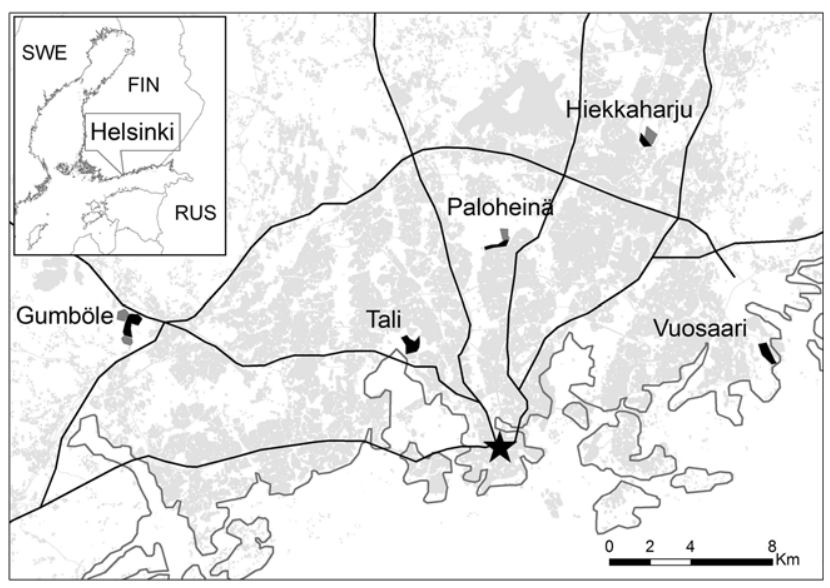

Fig. 1. Map of the study area showing the five golf courses and three areas to be used to extend the courses at Gumböle, Paloheinä and Hiekkaharju in the greater Helsinki area. Urbanized areas are in grey and the location of Helsinki city centre is marked by a star.

ticular golf course (see Appendix). Seventy traps were set at each of the two full-sized courses (Tali and Vuosaari). At the three 9-hole courses, 35 traps were placed in the current course area and another 35 traps in the areas into which the courses are to be extended (Gumböle, Hiekkaharju and Paloheinä). The reason for sampling the areas into which the golf courses are to be extended is to monitor the changes that might occur in the carabid beetle assemblages once the areas are developed as golf courses.

Continuous sampling started in early May 2007, with traps emptied three times between then and late September 2007. The carabid beetles were identified to species level using the keys in Lindroth $(1985,1986)$.

\section{Statistical analyses}

The pooled sample for each golf course and areas into which three are to be extended was used to evaluate the carabid beetle assemblage structure by means of rank-abundance plots, diversity indices and rarefaction curves. Species rank-abundance plots graphically depict the dominance and evenness structure (Magurran, 2004) of the beetle assemblages. Diversity and evenness indices reveal different aspects of the composition of the assemblages. Shannon's diversity $\left(\mathrm{H}^{\prime}\right)$ index takes into account species richness and the proportional abundance of each species in the sample, Shannon's evenness $\left(\mathrm{J}^{\prime}\right)$ index expresses the degree of evenness in species abundances, while Simpson's diversity (D) index reflects the probability that any two individuals drawn at random from a population will belong to the same species (Magurran, 2004). Finally, rarefaction curves reflect species richness that compensate for varying sample sizes, which is the case for the golf courses and areas into which they are to be extended sampled here. Rarefaction is a statistical method for estimating the number of species expected in a random sub-sample drawn from a larger sample (Simberloff, 1978; Magurran, 2004).

Comparisons of assemblage composition between the different golf courses were further explored using non-metric multidimensional scaling (NMDS). In this analysis sampling units included were vegetation type (individual vegetation plots sampled with five pitfall traps each), with abundance data of each beetle species collected per vegetation plot throughout the sampling period standardized to 100 trapping days. Each of the three trapping periods was standardised to 33.3 days, due to 


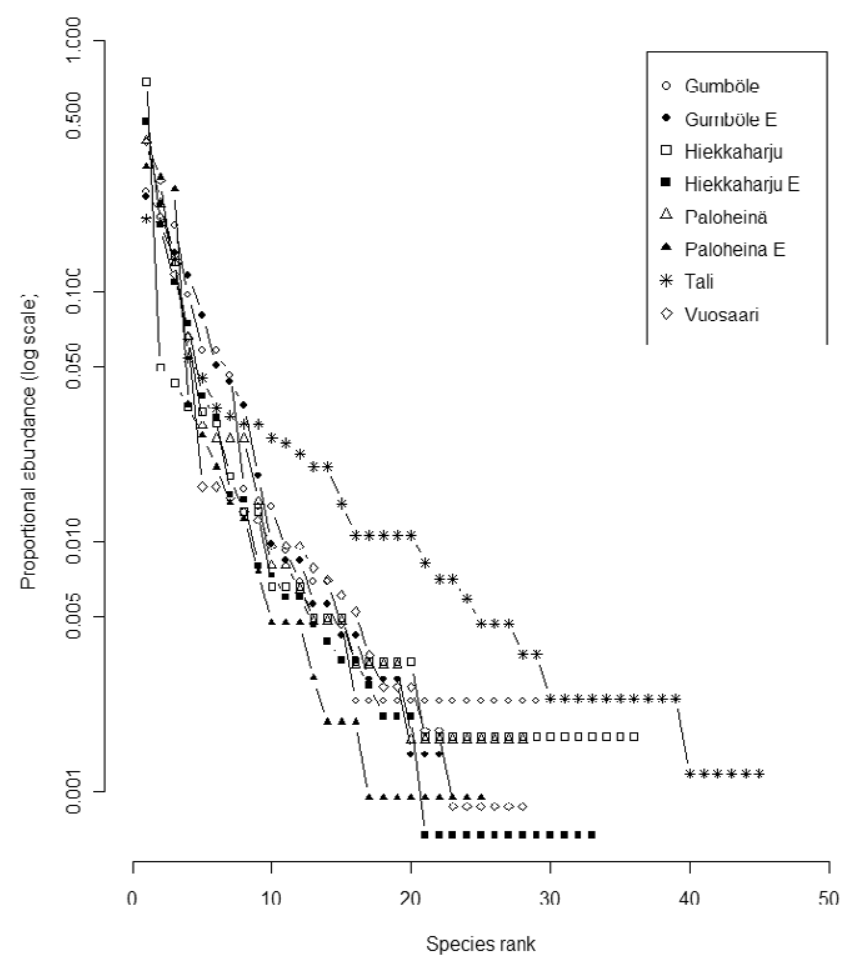

Fig. 2. Carabid beetle rank-abundance curves of the five golf courses and three areas into which the courses are to extend ("E" in the legend) in the greater Helsinki area.

high trap losses in certain vegetation types, possibly due to the curiosity of the golfing public. The Bray-Curtis index was used as a dissimilarity measure and the three-dimensional solution selected to minimize stress.

National frequency points were used as an indication of the scarcity of species. These indicate the number of $10 \mathrm{~km}$ grid squares in Finland from which the species have been recorded during the period 1960-1990 (Rassi, 1993).

Lastly, we explore the characteristics of the beetle communities by plotting the proportions of open habitat, generalist and forest individuals and species, the proportions of macropterous, wing dimorphic and brachypterous individuals and species, and the proportions of various size groupings of the beetles collected from the golf courses and the areas into which they are to be extended.

Statistical analyses were performed using the vegan package in the R statistical software (R Development Core Team, 2008).

TABLE 1. Carabid beetle diversity recorded at the five golf courses and three areas into which courses are to be extended. $\mathrm{H}^{\prime}=$ Shannon's diversity index, $\mathrm{J}^{\prime}=$ Shannon's Evenness, $\mathrm{D}=$ Simpson's diversity index, Species richness $=$ total number of species (Magurran, 2004).

\begin{tabular}{llcccc}
\hline & & $\mathrm{H}^{\prime}$ & $\mathrm{J}^{\prime}$ & $\mathrm{D}$ & $\begin{array}{c}\text { Species } \\
\text { richness }\end{array}$ \\
\hline Tali & Course & 2.80 & 0.42 & 0.90 & 45 \\
Vuosaari & Course & 1.82 & 0.26 & 0.75 & 28 \\
Paloheinä & Course & 1.94 & 0.30 & 0.77 & 28 \\
& Extended area & 1.70 & 0.24 & 0.75 & 25 \\
Gumböle & Course & 2.23 & 0.37 & 0.85 & 29 \\
& Extended area & 2.19 & 0.33 & 0.85 & 22 \\
Hiekkaharju & Course & 1.50 & 0.23 & 0.52 & 36 \\
& Extended area & 1.79 & 0.25 & 0.72 & 33 \\
\hline
\end{tabular}

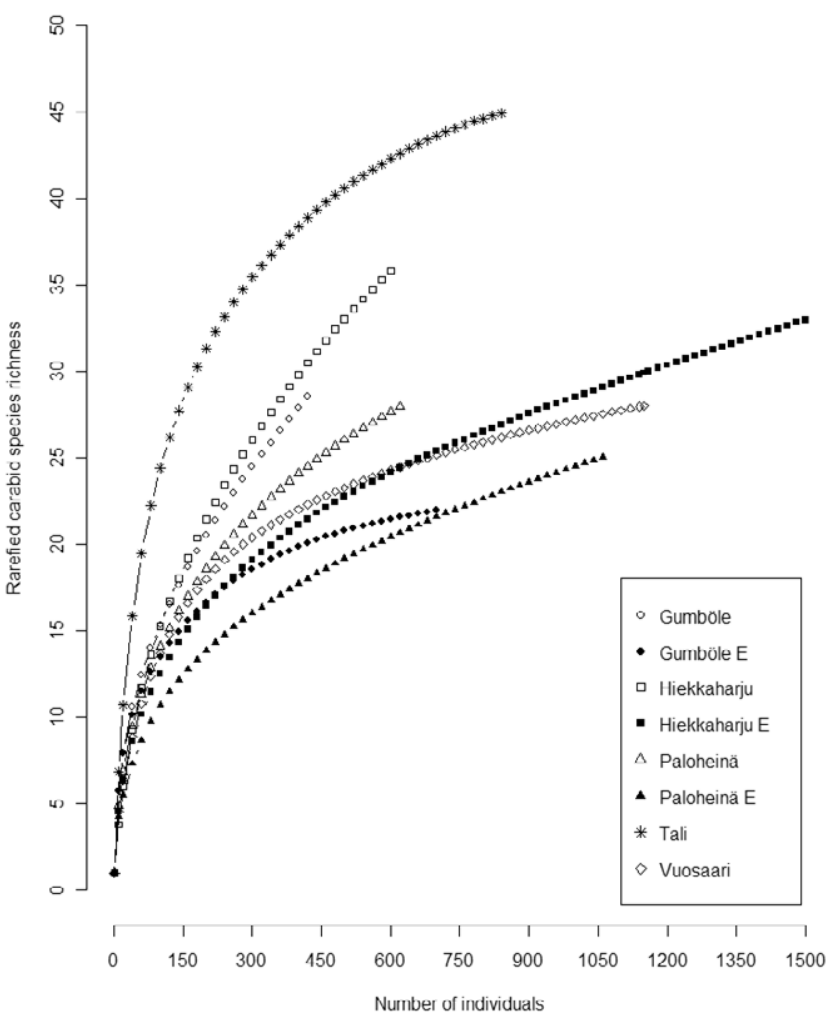

Fig. 3. Carabid beetle rarefaction curves of the five golf courses and three areas into which the courses are to extend ("E" in the legend) in the greater Helsinki area.

\section{RESULTS}

A total of 72 carabid species and 6944 individuals were collected during the study (Appendix). Pterostichus melanarius was the most abundant with 2105 individuals (30.3\% of the total catch), followed by Harpalus rufipes (1185 individuals, 17.1\%), P. niger (862 individuals, 12.4\%), Trechus secalis (479 individuals, 6.9\%), Poecilus versicolor (379 individuals, 5.5\%) and Calathus melanocephalus (316 individuals, 4.6\%). The number of beetles captured varied considerably between the golf courses: 2111 individuals (47 species) at Hiekkaharju, 1682 (36 species) at Paloheinä, 1149 (40 species) at Gumböle, 1148 (28 species) at Vuosaari and 854 (45 species) at Tali. Pterostichus melanarius was the most abundant species at four of the five courses $(19.4-39.4 \%$ of the total catch). The most abundant species at Gumböle was Trechus secalis $(24.2 \%$ of the total catch), followed by $P$. melanarius (17.4\%).

Tali, the oldest and most urban course, is characterised by a markedly even (Fig. 2), species rich and diverse (Table 1, Fig. 3) carabid assemblage compared to the other golf courses and areas into which they are to be extended. Note, however, that none of the rarefaction curves reached an asymptote (Fig. 3) and thus the actual species assemblages can be assumed to be larger than that indicated by this study.

The golf courses and the areas into which they are to be extended harboured markedly different carabid beetle assemblages (Fig. 4). Golf courses also differed from the areas into which they are to be extended by being gener- 


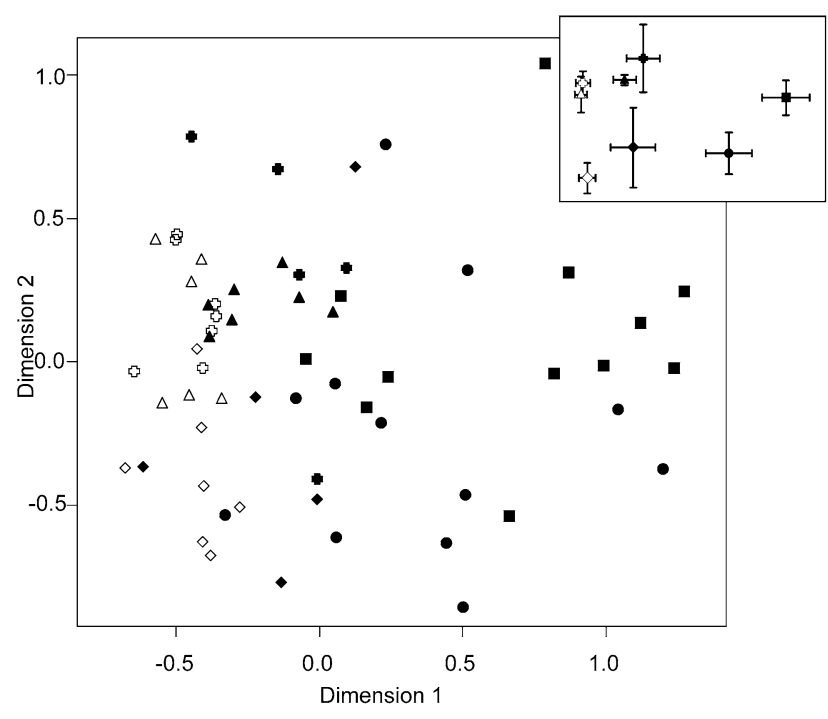

Fig. 4. Non-metric multidimensional scaling biplot showing the associations in carabid species assemblage composition between the five golf courses $(\boldsymbol{\square}=$ Vuosaari, $\boldsymbol{\bullet}=$ Tali, $\boldsymbol{\Delta}=$ Paloheinä, = Hiekkaharju, $=$ Gumböle) and three areas into which the courses are to extend ( $\rightsquigarrow=$ Hiekkaharju, $\triangle=$ Paloheinä and $\diamond=$ Gumböle). Insert: simplified plot showing means $\pm 2 \mathrm{SE}$ of the axes scores of the five courses and the three areas to be used to extend the associated courses.

ally species richer (Table 1, Fig. 3). Vuosaari, an open parkland course situated close to the sea, and Tali, the oldest and most urban golf course, were most distinct in their beetle assemblages from the other golf courses and the areas into which they are to be extended (Fig. 4). The other three golf courses (Gumböle, Hiekkaharju and Paloheinä) also formed relatively distinct clusters, but were more similar in beetle assemblages to the areas into which they are to be extended than to Vuosaari and Tali.

Paloheinä and Hiekkaharju golf courses and the areas into which they are to be extended (organically farmed field at Paloheinä and conventional field at Hiekkaharju) were dominated by the three most abundant species $(P$. melanarius, $P$. niger and $H$. rufipes), with over $75 \%$ of the catch consisting of these three species. At Gumböle, where the area into which it is to be extended is forest, the three most abundant species caught on the golf course ( $T$. secalis, $P$. niger and $H$. rufibarbis $-63 \%$ of the total catch) differed from those caught in the forest area into which the course is to be extended (T. secalis, P. melanarius and $P$. atrorufus $-60 \%$ of the total catch).

Open-habitat species ( $52 \%$ of all species collected) and generalist species (24\%) were common on the golf courses (Appendix), supporting the hypothesis that such species predominate at golf courses. Only $24 \%$ of the species collected were forest species. One individual of the regionally threatened species, Chlaenius nigricornis [Listed endangered (EN) in the IUCN red list of Finland] (Rassi et al., 2001), was collected at the edge of a pond at Hiekkaharju. None of the other species collected were of conservation concern. However frequency points (see above), identified four species of interest because of their higher frequency scores $(>30)$. Two of these (Trechus micros, Harpalus luteicornis) are generalists and two (Anchomenus dorsalis, Stomis pumicatus) are open habitat species. None of the forest species had scores higher than 15, suggesting that golf courses harbour no forest species of special concern.

The classification of species according to their habitat associations, wing morphology and body size are shown in Fig. 5. Generalist species, when compared to open habitat and forest species, were highly abundant both at golf courses and the areas into which they are to be extended. Golf courses were primarily characterised by open habitat and generalist species, while the areas into which they are to be extended had similar proportions of open habitat, generalist and forest species. In terms of wing morphology, both golf courses and the areas into which they are to be extended were mainly characterised by macropterous individuals and species. Few brachypterous individuals and species were trapped at golf courses and the areas into which they are to be extended. Large-sized $(10-15 \mathrm{~mm})$ individuals and medium-sized $(5-10 \mathrm{~mm})$ species were similarly common both at the golf courses and the areas into which they are to be extended.

\section{DISCUSSION}

Golf courses in Helsinki are characterised by a typically non-specialist, ruderal carabid beetle fauna. The oldest golf course had the highest beetle diversity, but lowest number of individuals, and at the three courses with areas into which it is proposed to extend the courses, the golf courses were more species rich than the areas into which they are to be extended. Carabid beetles found at the golf courses were primarily medium to large in size, capable of flight and generalist or open habitat species. In terms of their species assemblages, Tali (the oldest golf course) and Vuosaari (close to the sea) were most distinct while the areas into which the other courses are to be extended were more similar to that recorded at their nearby courses than that recorded at the full-size courses or at any of the other courses studied.

Generally, golf courses seem to be rich in invertebrates, such as carabid beetles and bumblebees (Gange et al., 2003; Tanner \& Gange, 2005). We collected 72 species from the five golf courses and the three areas into which they are to be extended, which is $32 \%$ of the species found in the geographical region of Uusimaa in Southern Finland and $18 \%$ of all the species found in Fennoscandia and Denmark (Lindroth 1985, 1986). It is likely that the high eurytopic species richness of golf courses is attributable to their high habitat diversity, ranging from strongly human-modified to more natural patches. The carabid communities differed between golf courses, even though visually similar vegetation types are present at most of the courses. This suggests that age, maintenance, human intensity (number of players) or the structure of the landscape play an important role in modulating the carabid beetle communities at these golf courses.

The least number of individuals, highest number of species, highest diversity (in terms of diversity indices and 


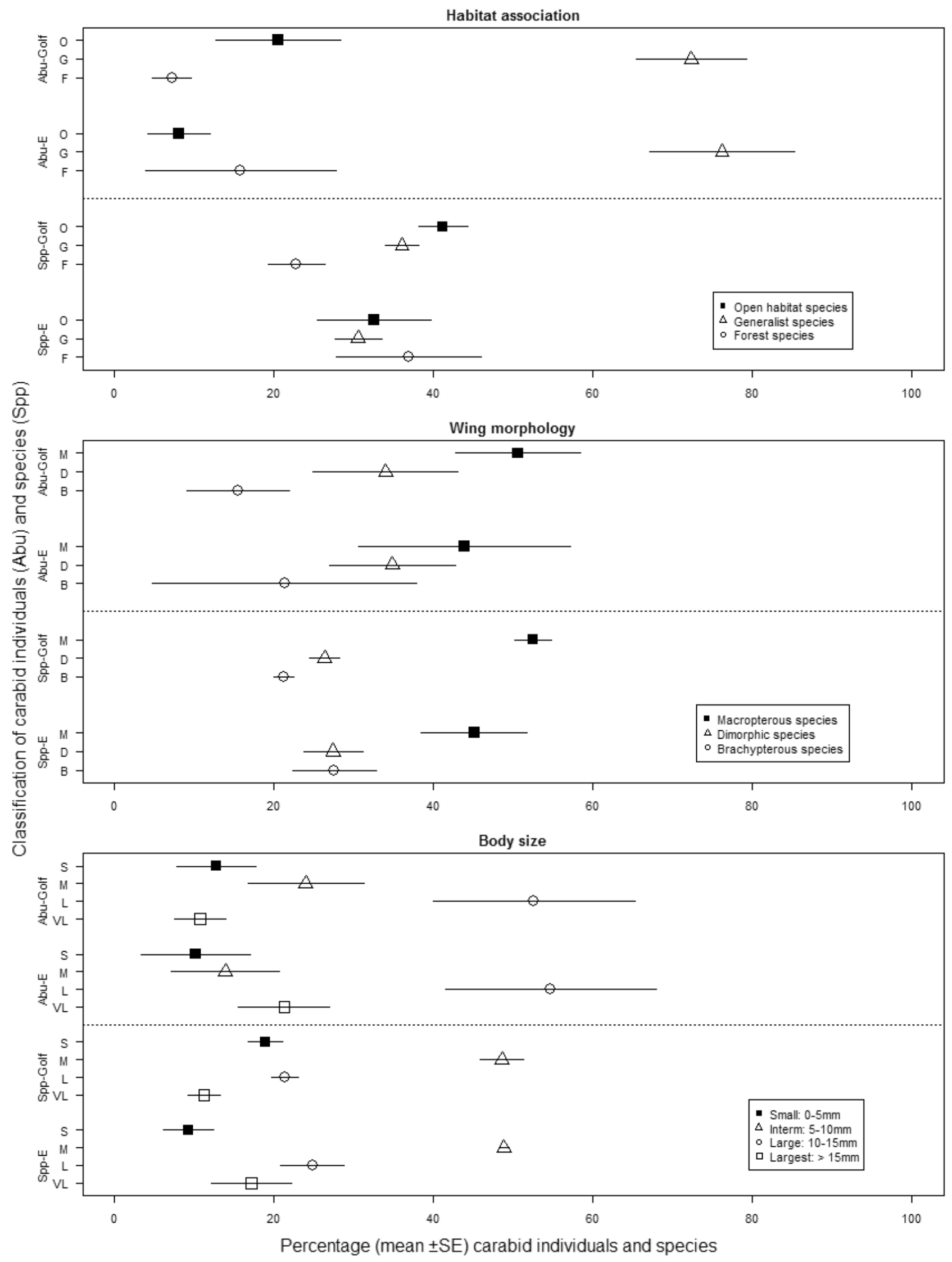

Fig. 5. Carabid beetle classification based on habitat association, wing morphology and body size. Each plot is divided into proportional abundances (top panel per plot) and species richness (bottom panel per plot). Abu $=$ abundance, Spp $=$ species richness, Golf $=$ golf course, $\mathrm{E}=$ areas into which the courses are to be extended. 
rarefaction curves) and evenness in carabid beetle fauna was that recorded for Tali golf course. The more evenly distributed and diverse carabid beetle assemblage at Tali may be because this course is old, more urban, has less disturbed vegetation and a highly variable environmental structure compared to the other courses. The mosaic of habitats at Tali includes old trees and ample canopy cover in a historically unique urban park whereas the two open courses (Paloheinä and Vuosaari) have hardly any tree cover. Although more beetles were trapped at the two open courses, the carabid communities there were dominated by a few abundant species. These courses are characterised by less environmental complexity or habitat heterogeneity and they seem to be favourable mainly for species associated with open habitats.

The generalist nature of the species collected (Appendix) and a lack of disturbance-sensitive species suggests that open-habitat carabid species are quick to colonize and establish populations in novel environments, such as golf courses. Even though the golf courses studied provide replicate open habitats that are rare in the urban landscape (such as sand banks and pond edges), they are currently not characterised by open-habitat specialist species of these types of habitat. Species associated with forest still thrive in forest fragments (area into which the course at Gumböle is to be extended) and at forest edges at golf courses, but are relatively uncommon. Only five species of interest were recorded at the golf courses and the areas into which they are to be extended (one included in the IUCN red list for Finland and four based on frequency points), none of which are forest specialists. Apart from Anchomenus dorsalis (25 individuals, collected from the field into which the course is to be extended at Hiekkaharju), the abundances of these species were low, further suggesting the low conservation value of golf courses in terms of carabid beetle assemblages. Anchomenus dorsalis (collected mainly from a conventionally farmed field at Hiekkaharju) is a relatively new species to the region and has recently colonized cultivated fields in Helsinki (Hans Silfverberg, pers. comm.).

In terms of assemblage composition, areas for proposed extensions to golf courses were highly distinct from that of the two full-sized courses (Tali and Vuosaari), but were more similar, yet distinct, to their adjacent 9-hole golf courses. This suggests that the carabid beetle assemblage in the immediate surroundings of a golf course contribute to the structure of the carabid assemblage recorded for the course. The transformation of a cultivated field or a forest into a golf course with a variable habitat mosaic most likely attracts new carabid species to the area, but may also restrict the abundance and occurrence of sensitive species and species associated with taller vegetation and/or canopy cover or moist environments.

Our results accord with the prediction that the carabid beetle assemblages associated with golf courses are dominated by generalist and open-habitat species. Yet, the areas into which the courses are to be extended (which consist of forest and agricultural land) are similarly domi- nated by generalist and open-habitat species. This suggests that both regional and local species pools affect the carabid beetle assemblages associated with golf courses in the greater Helsinki area. For example, at the regional level the five golf courses are quite distinct in their carabid beetle assemblage composition and this may be one reason for the high species richness observed across all the golf courses sampled. Locally, habitats in the surrounding environment (here, the areas proposed for the extended courses) seem to have an effect on the golf course fauna, as the fauna of these undeveloped areas are clustered close to their respective golf courses, which supports the suggestion that local and regional differences are important in structuring the assemblages of carabid beetles recorded at golf courses. At Paloheinä and Hiekkaharju, where the areas to be used for extending the courses are farmland, the species assemblages are more similar than at Gumböle, where the undeveloped area is forest. Furthermore, both golf courses and the adjacent undeveloped areas were equally dominated by macropterous carabids and large individuals (primarily P. melanarius and $H$. rufipes) and medium-sized species (mainly of the genera Amara and Harpalus).

It seems that even the tiny fragments of vegetation within golf courses support carabid beetles associated with the original vegetation of the area and that the assemblage is enriched by generalist and open habitatspecies once a golf course is constructed. The increased openness of the course area seems to lead to the dominance of the assemblages by a few species, while the age of the course promote a more even and species rich carabid beetle community. However, even the old golf course at Tali is dominated by generalist and open-habitat species, implying that golf courses may not provide suitable habitats for forest specialists. Golf courses are unlikely to become valuable habitats for stenotopic and poorly-dispersing species and because of management, will always be characterised by assemblages of eurytopic species.

The five courses studied cover some 165 ha of land, which is roughly half of the land set aside for nature protection (347 ha, $n=40$ ) in the city of Helsinki (Anonymus, 2008; excluding water surfaces). The allocation of such a large amount of urban land to a single form of recreation is remarkable, as land there is scarce for any purpose. Previous studies of meadows, semi-natural grasslands and lawns in Helsinki (Venn \& Rokala, 2005; Jokinen, 2007; Ketola, 2009) have shown that open habitats are valuable for maintaining carabid species richness, in and around urban centres, where land use changes have resulted in the loss and overgrowth of semi-natural open habitats. It is recommended that golf course management includes strategies for retaining habitats of regional biodiversity value and even creating potentially ecologically valuable habitats. In particular, out-of-play areas that do not necessarily need intensive management could be made more favourable for meadow species, which are in serious decline in this region (Pykälä, 2000; Raunio et al., 2008). 
Networks of protected areas alone are insufficient to halt the decline of biodiversity (Hunter, 2005; Sutherland et al., 2009). In urban areas, in particular, it is necessary to look for ways of integrating conservation management into land-use planning. Man-made environments, such as golf courses and other recreational areas, represent a major opportunity for the maintenance of urban biodiversity and should, therefore, have a high priority in land-use planning and urban biodiversity research.

ACKNOWLEDGEMENTS. We are grateful to the following golf course officials and green-keepers: I. Ulander and T. Marjamäki (Tali), J. Heikura and A. Fagerhom (Paloheinä), I. Kaivosoja (Vuosaari), R. Lehto (Hiekkaharju) and J. Viita-aho (Gumböle) who allowed us access to courses and provided information on management practices. We thank M. Konvička and an anonymous reviewer for constructive comments on an earlier draft of this manuscript. This study was funded by the European Networks Programme of the University of Helsinki, Finland and the Academy of Finland (Project number 126915).

\section{REFERENCES}

ANONYMus 2005: Statement of the Finnish Golf Union 27.5.2005.

http://www.hel2.fi/ksv/hela/Kaupunkisuunnittelulautakunta/E sityslistat/062330086.htm (accessed 20.3.2009) [in Finnish].

ANONYMUS 2008: Helsinki city nature conservation programme 2008-2017. Publications of Helsinki environment centre 16. 72 pages, 8 appendices [in Finnish].

Daniels J.C. \& EMmel T.C. 2004: Florida golf courses help save the endangered butterfly. USGA Turfgrass Envir. Res. Online 3: $1-7$.

Dodson R.G. 2000: Managing Wildlife Habitat on Golf Courses. John Wiley \& Sons, New York, 177 pp.

Farrally M.R., Cochran A.J., Crews D.J., Hurdzan M.J., Price R.J., Snow J.T. \& Thomas P.R. 2003: Golf science research at the beginning of the twenty-first century. J. Sports Sci. 21: 753-765.

Gange A.C., Lindsay D.E. \& Schofield J.M. 2003: The ecology of golf courses. Biologist 50: 63-68.

Grandchamp A.-C., Niemelä J. \& Kotze J. 2000: The effects of trampling on assemblages of ground beetles (Coleoptera, Carabidae) in urban forests in Helsinki, Finland. Urban Ecosyst. 4: 321-332.

HUNTER JR. M.L. 2005: A mesofilter conservation strategy to complement fine and coarse filters. Conserv. Biol. 19: $1025-1029$

Jokinen J. 2007: Effects of Mowing on Ground Beetle (Coleoptera, Carabidae) Assemblages of Urban Meadows. M.Sc. thesis. University of Helsinki, Dept. of Biological and Environmental sciences [in Finnish].

Ketola P. 2009: Effects of Urbanization and Management History on Carabid Beetles (Coleoptera, Carabidae) in Urban Meadows. M.Sc. thesis. University of Helsinki, Dept. of Biological and Environmental sciences [in Finnish].

LaukKanen K., SaArinen O. \& Walden H. 2006: Handbook of Golf Course Environment. Finnish Golf Union, 100 pp. [in Finnish].

Lindroth C.H. 1985, 1986: The Carabidae (Coleoptera) of Fennoscandia and Denmark. Fauna Entomologica Scandinavica 15, part 1, part 2. Scandinavian Science Press, Copenhagen, $514 \mathrm{pp}$.

Lopez R. \& Potter D.A. 2003: Biodiversity of ants (Hymenoptera: Formicidae) in golf course and lawn turf habitats in Kentucky. Sociobiology 42: 701-714.
MagurRan A.E. 2004: Measuring Biological Diversity. Blackwell, Oxford, $256 \mathrm{pp}$.

Niemelä J. 1999: Ecology and urban planning. Biodivers. Conserv. 8: 119-131.

Porter E.E., Pennington D.N., Bulluck J. \& Blair R.B. 2004: Assessing the conservation value of golf courses for butterflies. USGA Turfgrass Envir. Res. Online 3: 1-13.

PYKÄLÄ J. 2000: Mitigating human effects on European biodiversity through traditional animal husbandry. Conserv. Biol. 14: 705-712.

R Development Core Team 2008: $R$ : A Language and Environment for Statistical Computing. R Foundation for Statistical Computing, Vienna, URL http://www.R-project.org.

Rassi P. (ed.) 1993: Frequency Score of Coleoptera in Finland 1.1.1960-1.1.1990. Maailman Luonnon Säätiön WWF Suomen Rahaston Raportteja no 6. Helsinki, 136 pp. [in Finnish, English abstr.].

Rassi P., Alanen A., Kanerva T. \& Mannerkoski I. (eds) 2001: The Red List of Finnish Species. Ministry of the Environment, II Committee of the Monitoring of Threatened Species in Finland, Helsinki, 432 pp. [in Finnish, English abstr.].

Raunio A., Schulman A. \& Kontula T. (eds) 2008: Assessment of threatened habitat types in Finland. In: The Finnish Environment 8/2008. Parts 1 and 2. Finnish Environment Institute (SYKE), Helsinki, $264+572$ pp. [in Finnish, English abstr.].

Santiago M.J. \& Rodewald A.D. 2004: Considering wildlife in golf course management. Ohio State University Extension Fact Sheet. http://ohioline.osu.edu/w-fact/0015.html

Savard J-P.L., Clergeau P. \& Mennechez G. 2000: Biodiversity concepts and urban ecosystems. Landsc. Urban Plan. 48: 131-142.

SimBERLOFF D.S. 1978: Use of rarefaction and related methods in ecology. In Dickson K.L., Garins Jr. J \& Livingston R.J. (eds): Biological Data in Water Pollution Assessment: Quantitative and Statistical Analysis. American Society for Testing and Materials, STP 652, pp. 150-165.

StAngel P. \& Distler K. 2002: Golf courses for wildlife: Looking beyond the turf. USGA Turfgrass Envir. Res. Online 1: $1-8$.

Sutherland W.J., Adams W.M., Aronson R.B., Aveling R., Blackburn T.M., Broad S., Ceballos G., Cote I.M., Cowling R.M., Da Fonseca G.A.B., Dinerstein E., Ferraro P.J., Fleishman E., Gascon C., Hunter Jr. M., Hutton J., Kareiva P., Kuria A., MacDonald D.W., MacKinnon K., Madgwick F.J., Mascia M.B., McNeely J., Milner-Gulland E.J., Moon S., Morley C.G., Nelson S., Osborn D., Pai M., Parsons E.C.M., Peck L.S., Possingham H., Prior S.V., Pullin A.S., Rands M.R.W., Ranganathan J., Redford K.H., Rodriguez J.P., Seymour F., Sobel J., Sodhi N.S., Stott A., Vance-Borland K. \& Watkinson A.R. 2009: One hundred questions of importance to the conservation of global biological diversity. Conserv. Biol. 23: 557-567.

TANNER R.A. \& GANGE A.C. 2005: Effects of golf courses on local biodiversity. Landsc. Urban Plan. 71: 137-146.

TERMAN M.R. 1997: Natural links: naturalistic golf courses as wildlife habitat. Landsc. Urban Plan. 38: 183-197.

Thien S., Starrett S., Robel R., Shea P., Gourlay D. \& Roth C. 2004: A multiple index environmental quality evaluation and management system: application to a golf course. USGA Turfgrass Envir. Res. Online 3: 1-10.

TiLLY D. 2000: Golf course program produces many birds. $J$. North Am. Bluebird Soc. 22(1): 16.

VenN S. \& RoKala K. 2005: Effects of grassland management strategy on the carabid fauna of urban parks. In Sklodowski J., Huruk S., Barsevskis A. \& Tarasiuk S. (eds): Protection of 
Coleoptera in the Baltic Sea Region. Warsaw Agricultural

University Press, pp. 65-75.

Received November 27, 2009; revised and accepted March 29, 2010

APPENDIX. Carabid beetles caught at golf courses and the areas into which some of the courses are to be extended, in the greater Helsinki area. The total catch is grouped under courses and habitats, and the species categorized in terms of habitat affinity (Lindroth 1985, 1986). FP= national frequency points (see text and Rassi, 1993), Size = mean size in mm, Habitat: $G=$ generalist, $O=$ open habitat species, $F=$ forest species, $D=$ dry habitat, $\mathrm{M}=$ moist habitat, Wings: $\mathrm{D}=$ dimorphic, $\mathrm{M}=$ macropterous, $\mathrm{B}=$ brachypterous. Golf courses: $\mathrm{Gum} \mathrm{G}=\mathrm{Gumböle}$ golf course, Gum $\mathrm{E}=$ Gumböle area into which this course is to be extended, Hie G \& E = Hiekkaharju golf course and area into which this course is to be extended, Palo G $\& \mathrm{E}=$ Paloheinä golf course and area into which this course is to be extended, Tali $=$ Tali golf course, Vuo $=$ Vuosaari golf course. Habitats: Grass $=$ short vegetation, fairways, grass, Rough $=$ tall vegetation, roughs, $\mathrm{Road}=$ gravel roads, paths, Pond $=$ pond edge, Patch $=$ forest patch, $B$ irch $=$ birch patch, Edge = forest edge, Edge F = field edge, Bunker = sand bunker, Forest = forest in the area into which the course is to be extended. Values in brackets represent the number of groups of traps (5 traps per group) set.

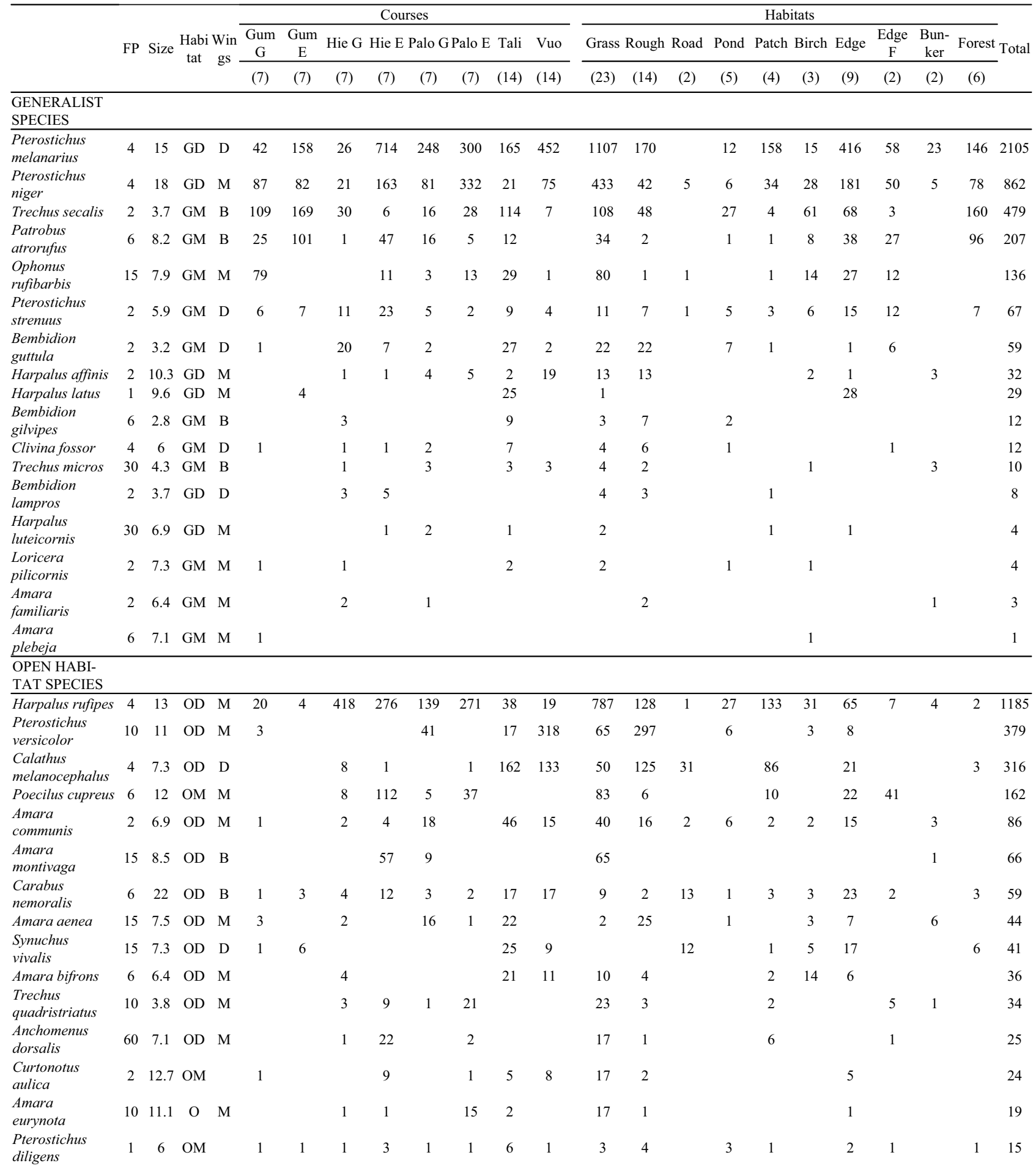




\begin{tabular}{|c|c|c|c|c|c|c|c|c|c|c|c|c|c|c|c|c|c|c|c|c|c|c|c|}
\hline $\begin{array}{l}\text { Leistus } \\
\text { ferrugineus }\end{array}$ & 15 & 7.3 & OD & $\mathrm{D}$ & & 3 & & & & & 9 & 1 & & & 7 & & 1 & & 2 & & & 3 & 13 \\
\hline $\begin{array}{l}\text { Syntomus } \\
\text { truncatellus }\end{array}$ & 4 & 2.9 & OD & $\mathrm{D}$ & & & 1 & & & & 9 & 3 & & 3 & & & & 9 & 1 & & & & 13 \\
\hline $\begin{array}{l}\text { Bembidion } \\
\text { properans }\end{array}$ & 10 & 3.9 & $\mathrm{OM}$ & $\mathrm{D}$ & & & 4 & 5 & & & 4 & & 2 & 5 & & 2 & 4 & & & & & & 13 \\
\hline $\begin{array}{l}\text { Calathus } \\
\text { erratus }\end{array}$ & 6 & 10.2 & OD & $\mathrm{D}$ & & & & & & & & 11 & 4 & 7 & & & & & & & & & 11 \\
\hline $\begin{array}{l}\text { Carabus } \\
\text { granulatus }\end{array}$ & 15 & 19.5 & $\mathrm{OM}$ & B & 6 & & 1 & 1 & & & 2 & & 1 & & & 2 & & 6 & & 1 & & & 10 \\
\hline $\begin{array}{l}\text { Pterostichus } \\
\text { nigrita }\end{array}$ & 6 & 10 & $\mathrm{OM}$ & M & & & 1 & 3 & 1 & & 3 & & & & & 4 & & & 4 & & & & 8 \\
\hline $\begin{array}{l}\text { Oodes } \\
\text { helopioides }\end{array}$ & 10 & 8.8 & $\mathrm{OM}$ & M & 1 & & & & & & 2 & & 2 & & & 1 & & & & & & & 3 \\
\hline $\begin{array}{l}\text { Dicheirotrichus } \\
\text { rufithorax }\end{array}$ & 15 & 4.3 & $\mathrm{O}$ & M & & & & & & & 2 & & 2 & & & & & & & & & & 2 \\
\hline $\begin{array}{l}\text { Amara } \\
\text { apricaria }\end{array}$ & 2 & 7.8 & OD & M & & & 1 & & & 1 & & & 2 & & & & & & & & & & 2 \\
\hline $\begin{array}{l}\text { Amara } \\
\text { municipalis }\end{array}$ & 20 & 6.7 & OD & M & & & 2 & & & & & & & 2 & & & & & & & & & 2 \\
\hline Amara ovata & 10 & 8.8 & OD & M & & & & & & & 2 & & 2 & & & & & & & & & & 2 \\
\hline $\begin{array}{l}\text { Notiophilus } \\
\text { germinyi }\end{array}$ & 4 & 6 & OD & M & 1 & & & 1 & & & & & & & & & & 1 & 1 & & & & 2 \\
\hline $\begin{array}{l}\text { Anisodactylus } \\
\text { binotatus }\end{array}$ & 15 & 11.4 & $\mathrm{OM}$ & M & & & 2 & & & & & & & 2 & & & & & & & & & 2 \\
\hline Dromius sigma & 4 & 3.6 & $\mathrm{OM}$ & B & & & & & 1 & & 1 & & & & & 1 & & & 1 & & & & 2 \\
\hline $\begin{array}{l}\text { Stomis } \\
\text { pumicatus }\end{array}$ & 30 & 7.6 & $\mathrm{OM}$ & B & & & & & 1 & 1 & & & & & & 1 & & & 1 & & & & 2 \\
\hline Trechus discus & 15 & 5 & $\mathrm{OM}$ & M & & & 1 & & 1 & & & & 1 & & & & & & 1 & & & & 2 \\
\hline Amara fusca & & 8.4 & OD & M & & & 1 & & & & & & 1 & & & & & & & & & & 1 \\
\hline Amara nitida & 10 & 7.9 & OD & M & & & & & & & & 1 & & & & & & & 1 & & & & 1 \\
\hline Amara quenseli & 10 & 7.6 & OD & $\mathrm{D}$ & & & & 1 & & & & & 1 & & & & & & & & & & 1 \\
\hline Amara tibialis & 20 & 5.1 & OD & M & & 1 & & & & & & & & & & & & & & & & 1 & 1 \\
\hline $\begin{array}{l}\text { Bradycellus } \\
\text { caucasicus }\end{array}$ & 2 & 3.5 & OD & $\mathrm{D}$ & 1 & & & & & & & & & & & & & 1 & & & & & 1 \\
\hline $\begin{array}{l}\text { Agonum } \\
\text { sexpunctatum }\end{array}$ & 6 & 7.3 & $\mathrm{OM}$ & M & 1 & & & & & & & & & & & & & 1 & & & & & 1 \\
\hline $\begin{array}{l}\text { Chlaenius } \\
\text { nigricornis }\end{array}$ & 40 & 11.3 & $\mathrm{OM}$ & M & & & 1 & & & & & & & & & 1 & & & & & & & 1 \\
\hline \multicolumn{24}{|l|}{$\begin{array}{l}\text { FOREST } \\
\text { SPECIES }\end{array}$} \\
\hline $\begin{array}{l}\text { Calathus } \\
\text { micropterus }\end{array}$ & 1 & 7.3 & FM & B & & 57 & 18 & 1 & & & 1 & 3 & & & & & & & 5 & & & 75 & 80 \\
\hline $\begin{array}{l}\text { Pterostichus } \\
\text { oblongopunc- } \\
\text { tatus }\end{array}$ & 2 & 10 & FM & M & 4 & 36 & 1 & & & 1 & 4 & 14 & & & 6 & 1 & & 5 & 15 & & & 33 & 60 \\
\hline $\begin{array}{l}\text { Carabus } \\
\text { hortensis }\end{array}$ & 6 & 25 & FD & B & 1 & 31 & & 3 & & & 1 & 2 & & & & & 1 & & 7 & & & 30 & 38 \\
\hline $\begin{array}{l}\text { Platynus } \\
\text { obscurus }\end{array}$ & 6 & 5.8 & FM & B & 25 & & & & 2 & 5 & 4 & & 3 & & & 2 & & 24 & 7 & & & & 36 \\
\hline $\begin{array}{l}\text { Cychrus } \\
\text { caraboides }\end{array}$ & 10 & 16.5 & FM & & & 25 & & & & 1 & & 1 & & & & & & & 6 & & & 21 & 27 \\
\hline $\begin{array}{l}\text { Badister } \\
\text { lacertosus }\end{array}$ & 15 & 6.7 & FM & M & 3 & & & 1 & 1 & 3 & 9 & 1 & 7 & & & & 5 & & 5 & 1 & & & 18 \\
\hline Amara brunnea & 2 & 6 & $\mathrm{FD}$ & M & & 6 & & & & & 2 & 6 & & & 6 & & 1 & 1 & & & & 6 & 14 \\
\hline $\begin{array}{l}\text { Harpalus } \\
\text { quadripunctatus }\end{array}$ & 4 & 10.8 & FM & & & 13 & & 1 & & & & & & & & & & & 9 & & & 5 & 14 \\
\hline $\begin{array}{l}\text { Trichocellus } \\
\text { placidus }\end{array}$ & 2 & 4.8 & FM & M & 7 & & & & & & 6 & & 1 & 3 & & & & 7 & 2 & & & & 13 \\
\hline $\begin{array}{l}\text { Platynus } \\
\text { assimilis }\end{array}$ & 15 & 10.5 & FM & B & & & & & & 8 & & & & & & & & & 8 & & & & 8 \\
\hline $\begin{array}{l}\text { Leistus } \\
\text { terminatus }\end{array}$ & 15 & 7 & FM & $\mathrm{D}$ & & 2 & & & 1 & 1 & 2 & & & & & & & & 5 & & & 1 & 6 \\
\hline $\begin{array}{l}\text { Notiophilus } \\
\text { biguttatus }\end{array}$ & 2 & 5.5 & $\mathrm{FD}$ & $\mathrm{D}$ & & 2 & & & & & 2 & & & & & & 2 & & & & & 2 & 4 \\
\hline $\begin{array}{l}\text { Agonum } \\
\text { fuliginosum }\end{array}$ & 1 & 6.7 & FM & B & 2 & & & & & & 1 & & 1 & & & 1 & & 1 & & & & & 3 \\
\hline $\begin{array}{l}\text { Carabus } \\
\text { glabratus }\end{array}$ & 4 & 26 & FM & B & & 2 & & & & & & 11 & & & & & & & & & & 2 & 2 \\
\hline $\begin{array}{l}\text { Notiophilus } \\
\text { palustris }\end{array}$ & 4 & 5.5 & FM & $\mathrm{D}$ & & & & 1 & & & 1 & & & & & & & & 1 & 1 & & & 2 \\
\hline $\begin{array}{l}\text { Dromius } \\
\text { schneideri }\end{array}$ & 6 & 6.1 & $\mathrm{~F}$ & & & & & 1 & & & & & & & & & 1 & & & & & & 1 \\
\hline $\begin{array}{l}\text { Carabus } \\
\text { violaceus }\end{array}$ & 10 & 25 & FD & B & & 1 & & & & & & & & & & & & & & & & 1 & 1 \\
\hline $\begin{array}{l}\text { Number } \\
\text { of individuals }\end{array}$ & & & & & 435 & 714 & 607 & 1504 & 624 & 1058 & 854 & 1148 & 3046 & 961 & 85 & 122 & 465 & 254 & 1050 & 229 & 50 & 682 & 6944 \\
\hline $\begin{array}{l}\text { Number } \\
\text { of species }\end{array}$ & & & & & 29 & 22 & 36 & 33 & 28 & 25 & 45 & 28 & 43 & 32 & 11 & 25 & 26 & 27 & 41 & 17 & 10 & 22 & 72 \\
\hline
\end{tabular}

